\title{
THE PLANTS OF CRYOLITHOZONE AS PERSPECTIVE PRODUCERS OF BIOLOGICALLY ACTIVE SUBSTANCES
}

\author{
(C) Petrov K. A., Perk A. A., Chepalov V.A.
}

Institute of Biological Problems of Cryolithozone, SB, Russian Academy of Sciences, Yakutsk, Russia

Biogenic stimulants are substances produced under certain conditioner animal and plant tissue $\left(4-8{ }^{\circ} \mathrm{C}\right.$ in darkness for several days) and possessing biological activity. Similar processes of the formation of biologically active substances (BAS) - biostimulators, may occur in natural conditions, especially in the regions where plants experience long-term low temperature stress (cryolithic zone). The aim of our work was to study seasonal profiles of BAS accumulation of plant pigments (carotenoids, chlorophyll) and fatty acids (FA) of the plants of Central and North-Eastern Yakutia. The following species were investigated: Pinus sylvestris, Picea obovata, Larix cajanderi, Betula platyphylla, Duschekia fruticosa, Equisetum variegatum, E. scirpoides, Psathyrostachys juncea, Elymus sibiricus, Elytrigia repens, Bromop- sis inermis, Avena sativa, Hordium vulgare, Eriophorum vaginatum. Pigment identification was performed by thin-layer chromatography, FA of lipids - using column chromatography. It was found that under long cold hardening the plants of cryolithic zone, particularly evergreen species and permanent grasses, significantly accumulate BAS, compared to summer period: carotenoids ( $\beta$-carotene, lutein, and other xanthophylls) and essential FA. In the conditions of sharply continental climate and permafrost, where there are no winter thawing, the aboveground organs of woody plants, first of all buds, needles, as well as grassy plants having gone under the snow in green state, durably preserve these substances. The plants of cryolithic zone may become a perspective source of BAS.

\section{COMPONENT COMPOSITION OF FATTY ACIDS IN EVERGREEN HORSETAILS OF YAKUTIA AFTER CRYOINFLUENCE}

\section{(C) Petrov K. A., Perk A. A., Chepalov V.A.}

Institute of Biological Problems of Cryolithozone, SB, Russian Academy of Sciences, Yakutsk, Russia

Two evergreen species of horsetails, Equisetum variegatum Schleich. ex Web. and E. scirpoides Michx., are valuable forage for herbivore animals in the North, especially after autumn-winter adaptation to low temperature stress (cryoinfluence). It was noticed that they possess the extraordinary ability to restore strength and skin-hair cover of animals and may be considered as perspective candidates for search of new medical agents. Cryoinfluence is one of the possible factors modifying the chemical composition of the plants, in particularly, lipids. Horsetails $E$. variegatum and $E$. scirpoides were collected in Central and North-Eastern Yakutia (the Pole of Cold of the Northern hemisphere) before and after cryoinfluence (summer-autumn and winter, respectively). Composition of fatty acids in aboveground parts of these plants was investigated using gaschromatography (Agilent Technology 6890 Chromatograph, US). The total content of fatty acids in both species depended little on the season and was $11.0-13.9 \mathrm{mg} / \mathrm{g}$ of dry substance. Significant changes were simultaneously found in the qualitative and quantitative composition of individual fatty acids. In summer and at the beginning of the autumn, 10-12 individual fatty acids were determined, in winter - 14-15 fatty acids. The composition of main fatty acids in E. variegatum and in E. scirpoides was: palmitic (C16:0) 33.5-40.7 and 30.7-36.2\% and linoleic (C18:2) 11.5-15.4 and 11.5-20.0\%, linolenic (C18:3) $20.4-32.4$ and $28.5-35.4 \%$. It is interesting to reveal the arachidonic acid in horsetails (C20:4) 1.4-3.2\%, which is very rare for other species of plants. In winter, the content of unsaturated fatty acids reached 60.0$63.8 \%$, and polyunsaturated fatty acids with F-vitamin activity (linoleic, linolenic, arachidonic) was 50.0$51.0 \%$. It was found a considerable amount of carotenoids in horsetails, including a unique rhodoxanthin, preventing the destruction of the $\mathrm{F}$ vitamin complex. Possibly, co-presence of large quantities of fatty acids and antioxidants in winter period brings to the observed positive effect of these plants on the animals' state. It opens interesting perspectives of their use as a source of raw plant material for medicine. 